\title{
太阳望远镜高精度导行方法
}

郭晶晶 ${ }^{(1)}$, 杨云飞 ${ }^{(2)}$ ，冯松 ${ }^{(2)}$, 季凯帆 ${ }^{(2)}$, 林佳本 ${ }^{(1 *}$ ，曾真 ${ }^{(1)}$, 王丙祥 ${ }^{(1)}$

(1) 中国科学院太阳活动重点实验室, 北京 100012;

(2) 昆明理工大学信息工程与自动化学院, 昆明 650051

* 联系人, E-mail: jiabenlin@bao.ac.cn

2015-07-28 收稿, 2015-08-18 修回, 2015-08-28 接受, 2015-10-28 网络版发表

国家自然科学基金 $(11263004,11373042,11427901)$ 和科学院知识创新工程(KJCX2-EW-T07)资助

摘要介绍了太阳望远镜实时高精度导行方法。利用大面阵CCD采集主望远镜的全日面 $\mathrm{H} \alpha$ 太阳像，实时获取 太阳质心数据, 并通过灰度阈值、质心位置判定、太阳像长短轴比率判定等多重逻辑消除云雾等不良天气带来的 噪声, 提高质心计算精度. 采用面向连接的 TCP/IP网络通信技术, 将质心数据传输到望远镜导行控制端, 进而驱 动望远镜轴系控制系统实现闭环控制. 上述硬件结构和软件算法相结合, 不仅实现了高精度导行, 还大大提高了 望远镜导行系统的稳定性. 同时, 面向连接的TCP/IP网络通信控制技术, 速度更快、更可靠, 系统移植更便捷, 并 为远程控制和观测提供了技术接口.

关键词太阳望远镜, 高精度导行, TCP/IP 通信, 大面阵 CCD 导行

怀柔太阳观测基地(Huairou Solar Observing Station, HSOS)是中国科学院国家天文台的重要观测基 地之一. 它是在国际太阳物理界享有高知名度的太 阳磁场和速度场观测研究基地和学术研究中心. 全 日面太阳磁场望远镜是怀柔太阳观测基地的重要观 测设备之一, 该望远镜于 2005年12月在国家天文台 怀柔太阳观测基地安装调试完成, 并于 2006年5月通 过验收投人常规观测. 原有的光电导行系统是通过 附加光路加小面阵 $\mathrm{CCD}$ 实现闭环导行控制 ${ }^{[1]}$. 至今, 原有系统已经使用了将近 10年, 部分器件已经老化, 系统性能大大下降. 为此, 近期进行了系统的更新与 改造.

本课题组对太阳望远镜高精度导行方法进行了 研究, 并针对怀柔观测基地全日面磁场望远镜提出 了以下解决方案: 用主望远镜中的 $\mathrm{H} \alpha$ 望远镜作为导 行跟踪望远镜实现闭环导行控制. 首先采集首张 $\mathrm{H \alpha}$ 太阳像, 二值化后计算质心, 存储质心坐标, 作为初
始值 (STA); 然后实时计算采集的太阳像质心，与 STA比较, 获取赤经、赤纬方向偏移量; 经过多重逻 辑判定，将达标偏差发送至望远镜轴系控制端; 控制 端根据接收到的偏差发送微调指令到伺服电机控制 器, 驱动电机调整望远镜位置, 从而矫正望远镜的跟 踪误差.

\section{1 太阳望远镜导行基本原理}

电子科学技术正在以前所未有的速度发展着, 同时也推动着其他自然科学和社会科学的发展.太 阳光学望远镜的导行方法自然顺势发展, 其经历了 一个点、线、面的辩证发展过程. 20 世纪 90 年代以前 的导行方法采用太阳像的一点或者几点作为导行依 据, 其结构比较简单, 有较快的响应速度, 但精度有 限, 其典型代表为四象限探测器法, HSOS的多通道 望远镜就是采用的这种模式. 20 世纪 80 年代以后, 线 阵探测器技术开始完善, 望远镜导行进人了线阵探 


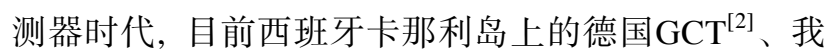
国曾经研制的球载望远镜等使用这种导行技术. 随 着计算机处理能力的提高, 面阵探测器在线阵探测 器的基础上逐步发展起来, 最早这种方案使用于空 间观测中, 例如, $\mathrm{SOHO}_{4}{ }^{[3]}$. 在 HSOS的多通道望远 镜、南京天文光学技术研究所的全日面太阳磁场望远 镜等地面观测中也有应用.

上述的系统都需要额外硬件系统, 本方案直接 使用主镜图像. 闭环控制对象准确, 无需额外的硬件 和额外的装配调试.

本系统利用大面阵CCD采集主镜全日面 $\mathrm{H} \alpha$ 图像 实现高精度导行, 依据全日面 $\mathrm{H} \alpha$ 图像的太阳质心位 置来反推望远镜指向的位置偏差, 实时驱动望远镜 轴系控制电机进行反馈修正, 实现闭环跟踪控制. 系 统设计的基本流程为: 采用大面阵 $\mathrm{CCD}$ 采集首张太 阳像, 计算质心, 作为 STA; 实时计算全日面 $\mathrm{H} \alpha$ 图像 的太阳质心, 与STA比较, 获取赤经、赤纬方向偏差 值; 根据所设条件國值判断偏差值是否有效, 通过 TCP/IP通信发送到控制终端计算机，计算机实时向 伺服电机控制系统发送微调命令, 从而实现闭环跟 踪控制. 闭环跟踪的系统框图如图 1.

\section{2 高精度导行系统设计}

\section{1 硬件构成}

（i ）全日面磁场望远镜. 全日面磁场望远镜 于2006年在怀柔观测基地建造完成，并投人常规观 测. 该望远镜的主要科学目标是监测强烈的太阳活 动, 例如, 太阳耀斑、太阳暗条以及研究它们与太阳 光球磁场和日冕物质抛射之间的关联. 因此, 全日面 磁场望远镜在同一底座上设计了两个望远镜：一个 是口径 $10 \mathrm{~cm}$ 的全日面矢量磁场望远镜，它能获得波 长为 $\mathrm{Fe} 5324 \AA$ 的全日面光球矢量磁场数据; 另一个 是口径 $20 \mathrm{~cm}$ 的色球望远镜, 它可获取波长为 $6562.8 \AA$ 的全日面 $\mathrm{H \alpha}$ 色球单色像. 滤波器中心波长控制在 $\mathrm{H \alpha}$ 线心上下 $2 \AA$ 之内 ${ }^{[4]}$. 2005 年年底太阳磁场活动望远镜 开始投入使用, 图 2 和 3 显示了太阳磁场活动望远镜的 结构和光路设计. 2012年更新了恒温器和电机控制系 统, 同时在观测软件中添加了自动观测模式 ${ }^{[5]}$.

本系统采用 $\mathrm{H} \alpha$ 望远镜作为高精度导行图像源， 整个系统架构利用望远镜的主镜成像作为控制输人 形成控制闭环，在实现科学数据采集的同时提供高 精度导行信号. 不需要额外增加导向望远镜和导行

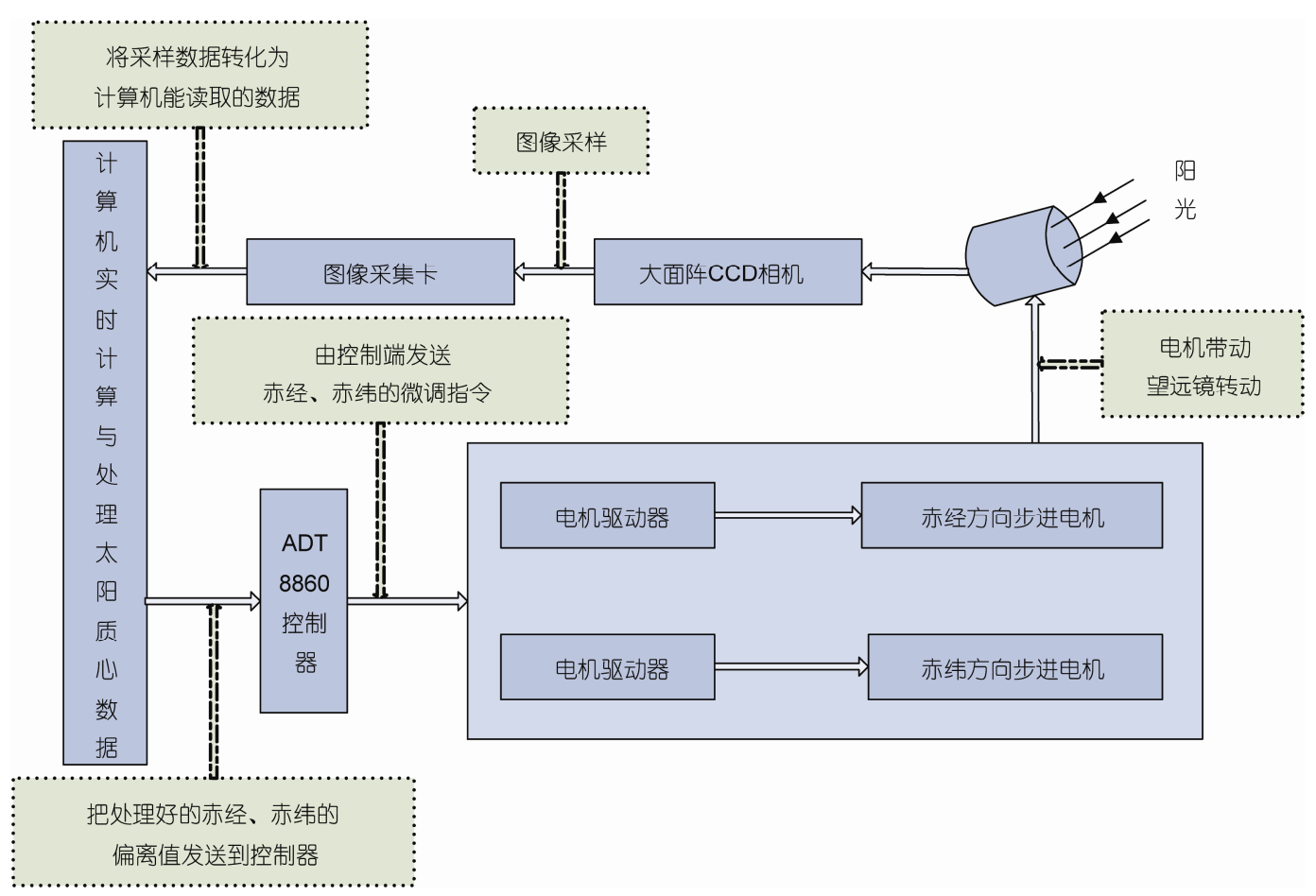

图 1 (网络版彩色)系统框图

Figure 1 (Color online) The system diagram 


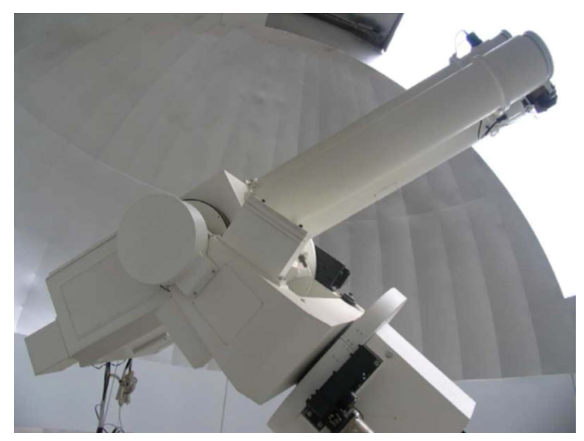

图 2 (网络版彩色)坐落在中国科学院国家天文台怀柔观测基地 (HSOS)的太阳磁场活动望远镜

Figure 2 (Color online) Solar Magnetism and the Activity Telescope (SMAT) at Huairou Solar Observing Station (HSOS) of the National Astronomical Observatories, Chinese Academy of Sciences (CAS)

$\mathrm{CCD}$, 大大降低了系统的硬件复杂度.

(ii) 数据采集 $\mathrm{CCD}$ 及计算机. $\mathrm{CCD}$ 探测器以其 灵敏、快捷、精确而日益得到广大天文工作者的青睐, 现已成为装备在现代光学天文望远镜上最主要的探 测工具之一 ${ }^{[6]}$. 全日面 $\mathrm{H \alpha}$ 望远镜图像尺寸为 18 $\mathrm{mm} \times 18 \mathrm{~mm}$, 采用大面阵CCD相机(PI EP16000)采集 全日面 $\mathrm{H} \alpha$ 图像. 这是一款高性能灰度深度可选 $(8$, 10,12 位) 的数字相机, 帧率为 $2.1 \mathrm{fps}$, 分辨率高达 4872 pixel $\times 3248$ pixel, 像素尺寸为 $7.4 \mu \mathrm{m} \times 7.4 \mu \mathrm{m}$. $\mathrm{CCD}$ 靶面远远大于太阳像, 因此通常使用2712 pixel×2712 pixel的区域采集数据. 采集端使用的主机为 DELL T7500, CPU为英特尔至强 $(\mathrm{R}) \mathrm{X} 5675$, 内存 12 GB DDR3, 并装配NVIDIA Tesla C1060 GPU卡. 根 据设计, 全日面 $\mathrm{H} \alpha$ 望远镜的空间分辨率优于 2 角秒 并且能够连续不断地获取图像.

(iii) 伺服电机及控制器. 伺服电机为三菱 HC-SFS52, 额定电压 $220 \mathrm{~V}$, 功率 $22 \mathrm{~kW}$, 速度相应
频率 $500 \mathrm{kHz}$. 最大转矩 $0.48 \mathrm{~N} \mathrm{~m}$, 额定转速 $3000 \mathrm{r} / \mathrm{min}$. 驱动器为三菱MR-J2S-60A, 采用了分辨率为 131072 脉冲/转的绝对位置编码器, 采用高性能的 CPU, 有较 好的响应性, 速度环路频率响应 $550 \mathrm{~Hz}$. 具有较好的 自动调谐性能，能够实现抑制机械振动，增益自动搜 索等功能. 共有3种控制电机模式: 速度控制、转矩控 制和位置控制. 速度控制和转矩控制都是用模拟量来 控制的，位置控制是通过发脉冲来控制的.

望远镜控制端接收来自采集端的偏差消息，发 送微调命令至伺服电机控制器, 控制器驱动伺服电 机系统, 调整望远镜位置, 实现望远镜实时精确的跟 踪太阳.

\section{2 高精度导行算法及软件设计}

( i ) $\mathrm{H} \alpha$ 望远镜观测软件. $\mathrm{H} \alpha$ 望远镜的观测软 件 ${ }^{[7]}$ 是在 VS2010的开发平台下，使用面向对象的 $\mathrm{C}++$ 语言开发的. 观测软件的采集流程是：初始化相 机, 开启图像采集线程，将采集的图像实时显示并保 存到数组中，根据设定的时间间隔把数组数据写成 FITS图存到磁盘. 高精度导行系统的数据采集端是 直接嵌人到 $\mathrm{H} \alpha$ 太阳像的观测软件中. 在观测软件的 界面，设计了两个按钮，“Location”和“Adjust(变为 Adjusting开始导行)”. 首先, 计算太阳质心的初始位 置(“Location”); 然后是“Adjusting”, 开启与控制器的 连接, 设置定时器. 在定时器中, 定时复制存储实时 图像数据的数组数据, 计算质心, 采集偏差信息, 输 出信号到控制端.

算法设计一太太阳质心的准确获取方法. (1) 计 算条件: 由于在天气不佳(如有云遮挡太阳等)、望远 镜跟踪过程中有一部分太阳像偏出视场等环境下,

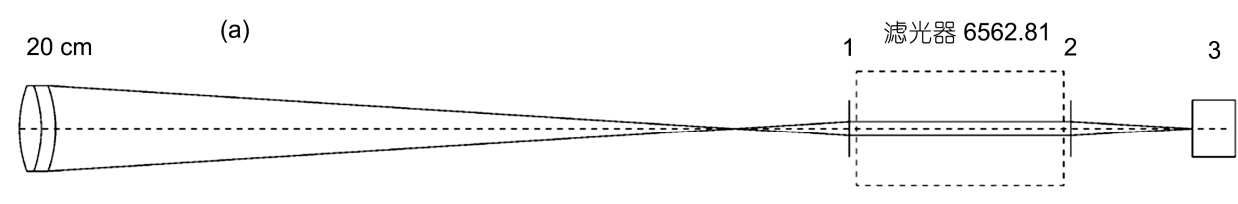

(b)

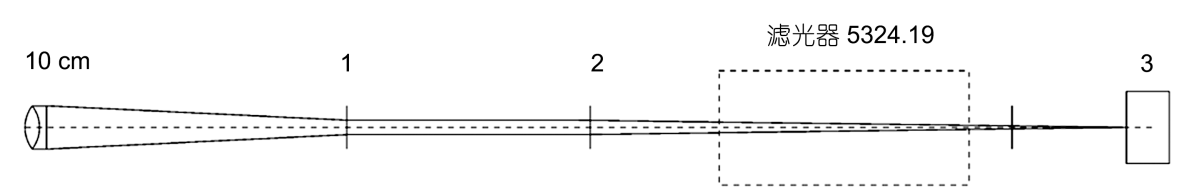

图 3 全日面矢量磁场望远镜(a)和全日面 $\mathrm{H} \alpha$ 望远镜(b)光学设计. 1, 准直透镜; 2, 聚焦透镜; $3, \mathrm{CCD}$ 相机

Figure 3 Optical scheme of full disk vector magnetograph (a) and full disk H_telescope (b). 1, Collimator lens; 2, focus lens; 3, CCD camera 
会造成 CCD采集的太阳像不完整, 且望远镜在此环 境中容易出现误动作损坏设备. 因此, 为使计算的质 心准确有效, 本系统中只有达到判定条件的图像, 才 会被计算偏差，其他的则剔除. 依据的判定条件如下.

第一层判定条件为: 图像的平均亮度 $(A V E)$ 需超 过所设亮度阈值(阈值取观测质量较好情况下的平均 亮度的 $30 \%$, 保证视场中有太阳), AVE计算如下：

$$
A V E=\frac{\sum_{i=1}^{M} \sum_{j=1}^{N} f(i, j)}{M \times N},
$$

其中, $M$ 为图像宽度, $N$ 为图像高度, $f(i, j)$ 为当前像素 亮度值。

第二层判定条件为：太阳的质心在 $\mathrm{CCD}$ 中心的 一个局部区域内(假设太阳像视场为 2700 pixel $\times 2700$ pixel, 太阳直径为 2300 pixel, 如果质心距离中心点 在横或纵方向的距离大于 240 pixel, 则认为太阳局部 出视场, 不进行偏差矫正). 为了消除云等干扰因素 的影响、配合第三重判定条件, 在此处设置了比常规 方法更严苛的限定条件. 后面将进一步研究判别算 法一对云遮和局部出视场的状况进行分别判定, 从 而实现在太阳局部出视场的情况下, 仍能使太阳像 回到视场中心, 同时还能消除云的干扰. 理想情况 下, 全日面太阳边缘几乎是正圆, 如果把它看作是一 个椭圆, 那么它比率 $E$ 值为 $1^{[8]}$. 因此, 可以用比率 $E$ 来量化太阳像与正圆的偏差. 在天气良好的状况下, 太阳像的比率 $E$ 为 $1.0010 \pm 0.0015^{[8]}$. 避免天气状况不 佳时, 望远镜出现误动作, 损坏设备, 设置第三层判定 条件: 比率 $E$ 在 1.2 以内. $E$ 的计算如下:

$$
E=\frac{a}{c},
$$

其中, $a$ 为长轴, $c$ 为短轴, $a, c$ 的具体计算方法参见文 献[7].

（2）计算方法: 太阳的形状和位置容易受大气抖 动的影响, 解决的办法就是先对图像 “二值化”, [9], 然 后计算质心. 从图像采集卡获取太阳像中心面积区 域(2712 pixel×2712 pixel), 根据OTSU算法 ${ }^{[10]}$ 求得像 素点的阈值, 下面简要描述OTSU算法.

计算输人的全日面像的直方图，使用 $p_{i}, i=$ $0,1,2, \cdots, L-1$ 表示该直方图的各个分量.

由公式(3)计算累积和 $p_{1}(k)$, 其中 $k=0,1,2, \cdots, L-1$ :

$$
p_{1}(k)=\sum_{i=0}^{k} p_{i} \text {. }
$$

由公式(4)计算累积均值 $m(k)$, 其中 $k=0,1,2, \cdots$, $L-1$ :

$$
m(k)=\sum_{i=0}^{k} i p_{i} .
$$

由公式(5)计算全局灰度均值 $m_{G}$ :

$$
m_{G}=\sum_{i=0}^{L-1} i p_{i} .
$$

由公式 (6) 计算类间方差 $\sigma_{B}^{2}(k)$, 其中 $k=0,1,2, \cdots, L-1$ :

$$
\sigma_{B}^{2}(k)=\frac{\left[m_{G} P_{1}(k)-m(k)\right]^{2}}{P_{1}(k)\left[1-P_{1}(k)\right]} .
$$

使类间方差 $\sigma_{B}^{2}(k)$ 最大的 $k$ 值，即为 OTSU阈值 $T$. 定义太阳像中某一点像素值为 $f(x, y)$, 通过國值 T进行分割:

$$
g(x, y)= \begin{cases}1, & f(x, y)>T, \\ 0, & f(x, y) \leqslant T .\end{cases}
$$

即由公式(7)把图像二值化，计算其重心，即质 心，然后计算偏差. 计算质心的方法有很多种，而经 试验每种算法的差别不大.

位置偏差矫正方法. 基本算法思想: 首先计算图 像初始质心值为 $(x 0, y 0)$, 其他任意时刻获取的图像 质心为 $(x 1, y 1)$, 则偏差计算如下:

$$
d x=x 1-x 0, \quad d y=y 1-y 0 .
$$

根据实时获取的图像计算偏差值 $d x, d y$, 对连续 3 次的 $d x, d y$, 如果其相邻两次差值均在一个阈值内 (避免出现质心大幅度偏离, 望远镜误调整出现危险 状况), 则从图像采集端发送偏差到轴系控制端. 其 流程图见图4.

(ii) 轴系控制软件. 轴系控制软件接收来自采 集端的偏差消息, 发送微调命令至ADT8860控制器, 控制器通过伺服驱动器驱动电机，从而调整望远镜 位置, 实现望远镜实时精确的跟踪太阳. 轴系控制软 件是在 VC6.0平台下开发，依托 $\mathrm{MFC}^{[11]}$ 类库来实现 软件界面. 轴系控制软件设计主要有两大功能模块: 恒动控制和高精度导行控制. (1) 恒动控制. 恒动采 用伺服电机连续匀速运动方式，即伺服驱动器的速 度控制模式驱动电机. 根据相应的公式与参数, 计算 出太阳赤经方向的运动速度，然后根据望远镜的传 动减速比计算出电机恒动转速, 由电机驱动器控制 输出. (2) 高精度导行控制. 高精度导行控制是依据 偏差信号, 采用位置控制的模式驱动电机, 消除偏差, 


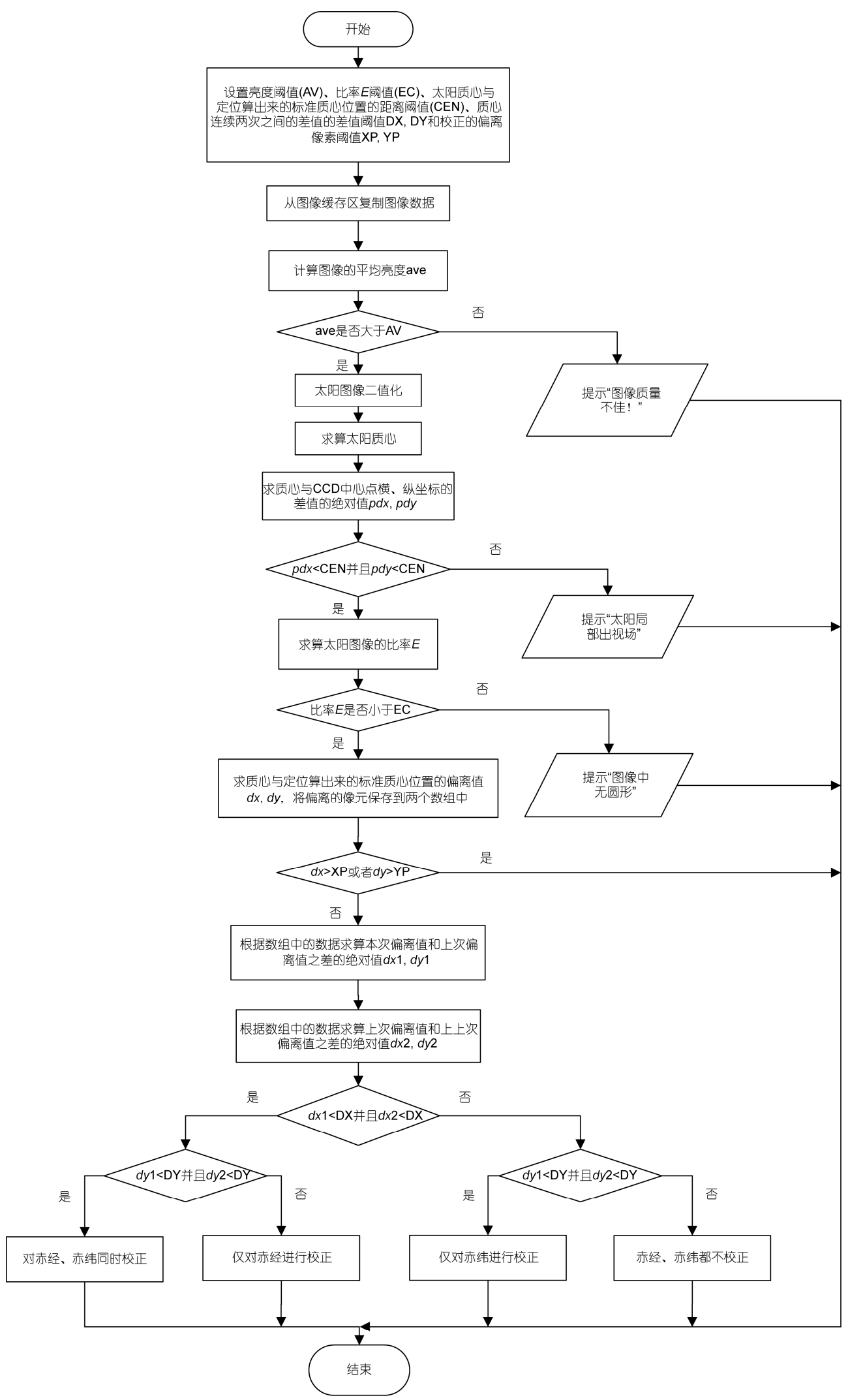

图 4 望远镜偏差矫正流程图

Figure 4 Corrective flowchart of telescopes' deviation 
使太阳像回到初始位置. 软件主要实现: 创建 socket 套接字, 监听采集端的 socket端口, 实时接收来自采 集端的偏差消息, 依据偏差发送相应的控制微调命 令到控制器, 驱动伺服电机, 调整望远镜位置, 实现 高精度导行控制. 轴系控制端设计了以下两种调整 方法. (1) 位置调整方法. 位置调整是指依据偏差, 以固定速度或加/减速度输出指定数量的脉冲, 驱动 望远镜移动到正确的位置. (2) 速度调整方法. 速度 调整是指依据偏差, 上下微调恒动的速度, 以此来校
正望远镜跟踪偏差.

\section{3 测试结果}

\section{1 测试结果与分析}

本系统于2014年8月 5 11日在中国科学院国家天 文台怀柔观测基地进行了首次现场联调，高精度导 行系统测试的结果见图5.

图5(a)明显可见：除了太阳运动产生的长期漂移
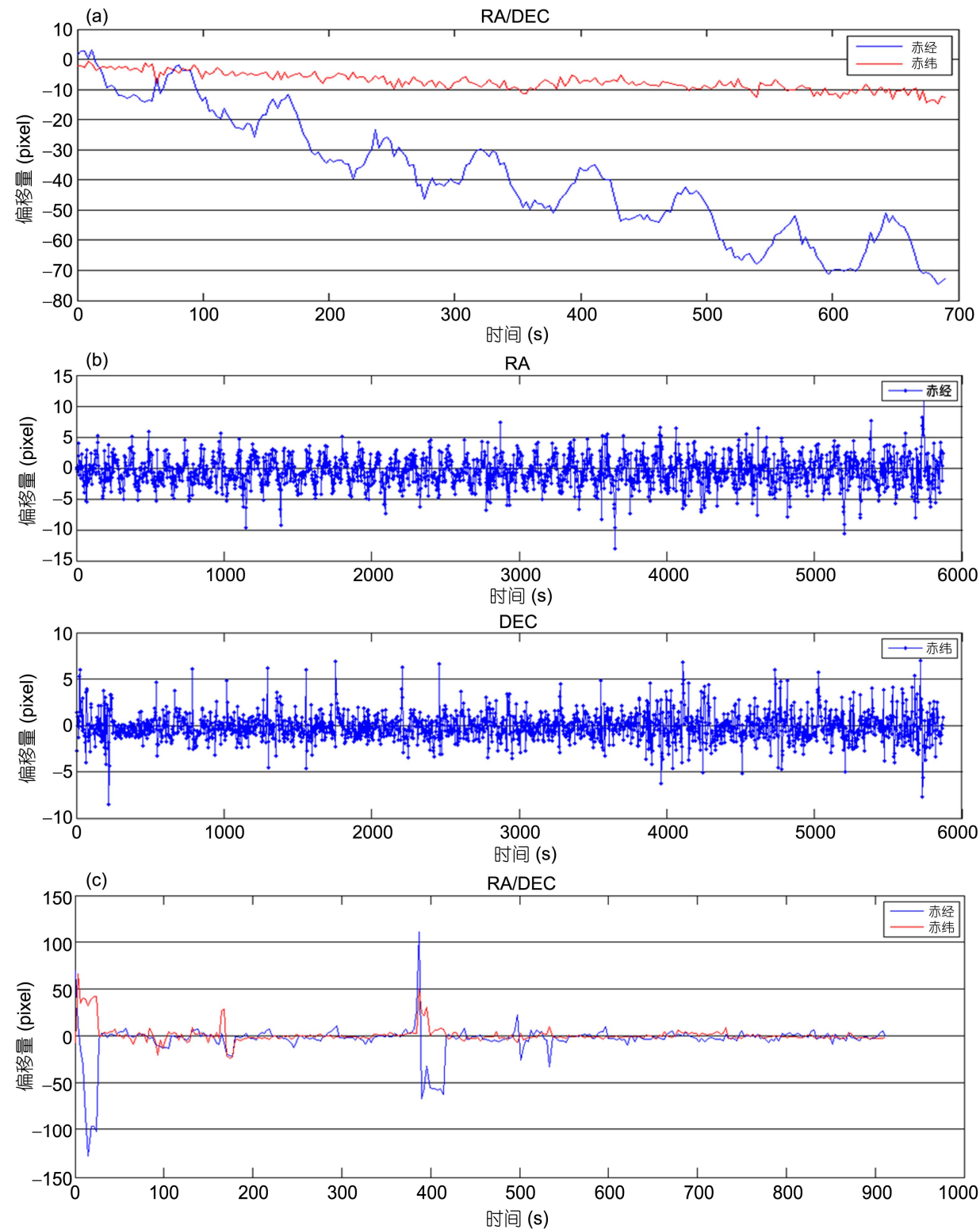

图 5 高精度导行系统测试结果. (a) 恒动下的赤经的周期振荡; (b) 天气晴朗下 $1 \mathrm{~h}$ 的导行跟踪; (c) 空中有云情况下导行跟踪

Figure 5 The test results of high precision guide system. (a) Periodic oscillation of RA in perpetual motion; (b) guiding track on sunny weather in an hour; (c) guiding track on cloudy weather 
外, 赤经方向有明显的周期震荡. 这个震荡对导行的 精度有很大的影响; 相对于赤经, 在赤纬方向偏移量 较小.

图 5(b)为在天气晴朗的状况下, 太阳质心在赤 经、赤纬方向的偏差变化. 赤经方向上的偏差集中在 上下 5 个像元范围内, 只有少数峰值突破 5 个像元; 赤 纬方向能够控制在上下两个半像元之间. 另一方面, 可以看出, 本系统很好地跟踪了太阳, 一个小时后太 阳基本还在初始位置. 表明本系统能够长时间稳定 的高精度导行控望远镜. 另外, 可以看出会有瞬间大 幅波动, 这与震荡周期有一定关系.

图 5(c)为空中有云飘过时的高精度导行, 其中赤 经赤纬有大波动的地方便是有云遮挡的时刻, 此时, 虽然计算的质心不准确, 但是望远镜没有误动作, 并 且云过后能很好地稳定导行.

\section{2 进一步提高全日面磁场观测精度的方法讨论}

与 $\mathrm{H} \alpha$ 望远镜同轴的全日面太阳磁场望远镜 ${ }^{[12]}$, 其高分辨的磁场观测需要采用积分的方法才能够实 现, 图像的空间分辨率是由地球大气抖动情况和望 远镜自身的跟踪精度决定的 ${ }^{[13]}$. 为了减少由于望远 镜跟踪误差造成的图像模糊, 我们提供了下面的提 高观测方便率的可能方案.

由图5(a)可以看出, 两个震荡周期之间有一段平稳
期，时间持续大约 $30 \mathrm{~s}$ (图6), 这段时间内偏差在 3 pixel 以内. 每 $15 \mathrm{~min}$ 观测一次, 每次观测持续的时间不到 30 s. 观测时间定位到平稳期将提高观测的质量, 利用自 相关算法计算出振荡周期为 $81 \mathrm{~s}$. 设置阈值, 在连续 3 次的偏差在 2 pixel内的时间点, 即为平稳期. 在后面观 测期间每隔 $81 \mathrm{~s}$ 提示观测人员为最佳观测期.

\section{4 结论}

高精度导行是太阳光学望远镜系统中的一项关 键技术, 为了获取高质量太阳图像, 望远镜长时间稳 定的高精度导行至关重要. 本系统采用主望远镜 $\mathrm{H \alpha}$ 的图像信号作为控制输人并形成控制闭环, 实现了 准确的跟踪导行, 并通过多重条件的逻辑限定大大 提高了导行系统在恶劣天气条件下的抗干扰能力, 提出了提高全日面磁场观测分辨率的可行方案. 另 外, 本系统采用了面向连接的端到端的 TCP/IP传输 模式, 提高了传输的可靠性, 保证了系统的稳定性. 通过对望远镜硬件构造的检测，赤经方向出现的周 期性振荡, 初步判断是由于望远镜传动机构的精度 不够造成的, 在一个月的系统试运行过程中, 系统工 作稳定, 精度指标达到要求; 在以后的望远镜中, 为 了实现更高精度的导行, 需要首先保证采用高精度 传动机构. 数据结果表明本文采用的方法有效, 可应 用于导行精度要求更高的望远镜系统.
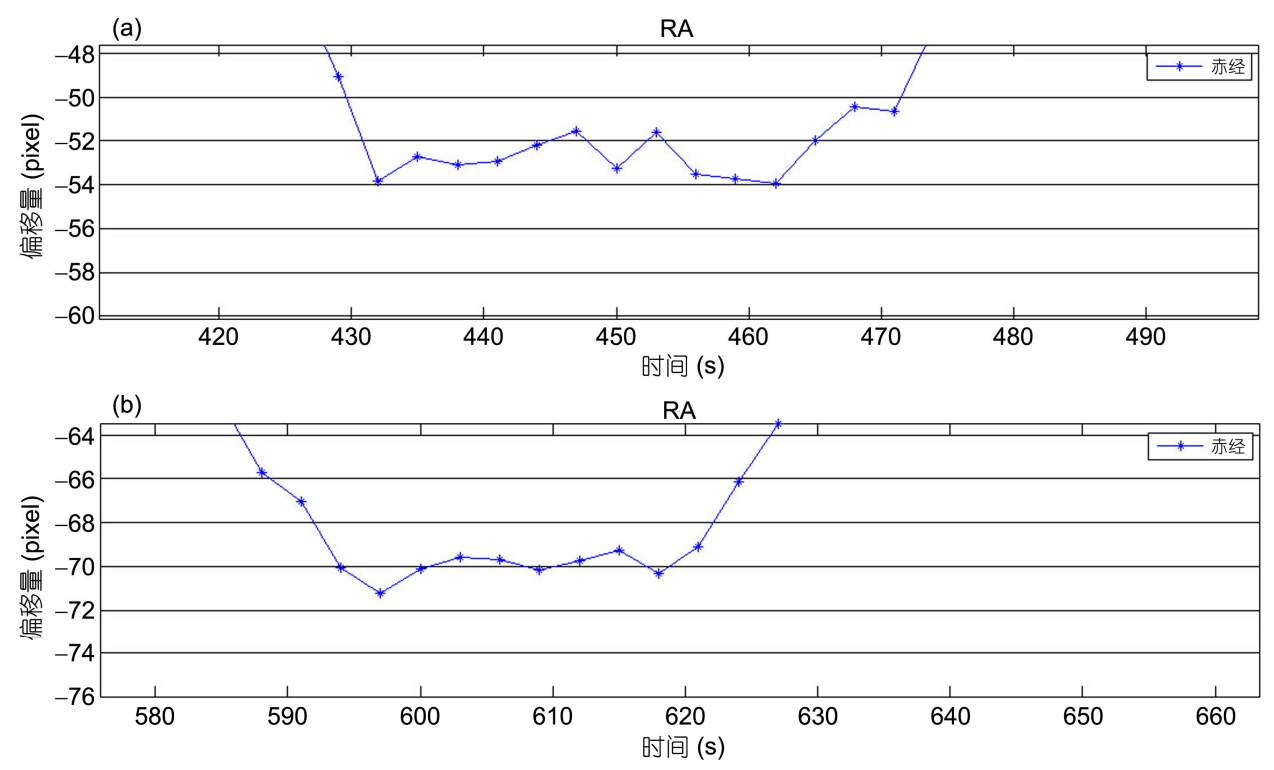

图 6 (网络版彩色)平稳期 1 (a)和 2 (b)

Figure 6 (Color online) Stationary phase 1 (a) and 2 (b) 

士在本文的撰写过程中给予了宝贵意见; 昆明理工大学云南省计算机技术应用重点实验室给予了技术支持. 对 以上单位及个人深表感谢.

\section{参考文献}

1 Wu C H, Zhu Q S, Zhou X J. The tracking and guiding method for full solar disk vector magnetograph telescope (in Chinese). Astron Res Tech, 2007, 6: 146-152 [吴春晖, 朱庆生, 周小军. 全日面太阳光学和磁场望远镜的自动跟踪与导行方法. 天文研究与技术, 2007, 6: 146-152]

2 Kuveler G, Wiehr E, Thomas D, et al. Automatic guiding of the primary image of solar gregory telescopes. Sol Phys, 1998, 182: 247-255

3 Thompson W, Carter M. EUV full-sun imaging and pointing calibration of the SOHO/CDS. Sol Phys, 1998, 178: 71-83

4 Zhang H Q, Wang D G, Deng Y Y, et al. Solar magnetism and the activity telescope at HSOS. Chin J Astron Astr, 2007, 7: 281-288

5 Lin J B, Shen Y B, Zhu X M, et al. Design of the automatic observation system for full-disk solar magnetograms in the HSOS (in Chinese). Astron Res Tech, 2013, 10: 392-396 [林佳本, 沈洋斌, 朱晓明, 等. 怀柔太阳观测基地全日面磁场自动化观测系统. 天文研 究与技术, 2013, 10: 392-396]

6 Ji K F, Mao W. CCDs in ground-based astrometry (in Chinese). Prog Astron, 1994, 12: 83-90 [季凯帆, 冒蔚. CCD 探测器在地面天体 测量中的应用. 天文学进展, 1994, 12: 83-90]

7 Lin J B, Deng Y Y, Hu K L. Application of LCT in solar magnetic field observation (in Chinese). Comput Eng Appl, 2006, 27: 203-205 [林佳本, 邓元勇, 胡柯良. 局部相关跟踪算法在太阳磁场观测中的应用. 计算机工程与应用, 2006, 27: 203-205]

8 Feng S, Lin J B, Yang Y F. Automated detecting and removing cloud shadows in full-disk solar images. New Astron, 2014, 32: 24-30

9 Xiao J, Hu K L, Lin J B. Tracking and guiding for full solar disk image using large CCD-array (in Chinese). Opt Precis Eng, 2008, 16: 1589-1594 [肖江, 胡柯良, 林佳本. 用大面阵 CCD 实现全日面像自动导行. 光学精密工程, 2008, 16: 1589-1594]

10 Gonzalez R C, Woods R Z. Digital Image Processing (in Chinese). Beijing: Beijing Industry Press, 2010 [Gonzalez R C, Woods R Z. 数 字图像处理. 北京: 电子工业出版社, 2010]

11 Yao L T. Proficient in MFC Programming (in Chinese). Beijing: Posts and Telecom Press, 2006 [姚领田. 精通 MFC 程序设计. 北京: 人民邮电出版社, 2006]

12 Ai G X, Hu Y F. Multichannel birefringent filter. I. Principle and video spectrograph. Sci China, 1987, 30: 868-876

13 Lin J B, Deng Y Y, Hu K L, et al. A method of intelligent solar flare data observation (in Chinese). PRC Patent, 201010185894. 201010-27 [林佳本, 邓元勇, 胡柯良, 等. 一种智能化太阳耀斑数据观测方法. 中国专利, 201010185894. 2010-10-27] 


\title{
High precision guide method for the solar telescope
}

\author{
GUO JingJing $^{1}$, YANG YunFei ${ }^{2}$, FENG Song ${ }^{2}$, JI KaiFan ${ }^{2}$, LIN JiaBen ${ }^{1}$, ZENG Zhen ${ }^{1}$ \& \\ WANG BingXiang ${ }^{1}$ \\ ${ }^{1}$ Key Laboratory of Solar Activity, Chinese Academy of Science, Beijing 100012, China; \\ ${ }^{2}$ Faculty Information Engineering and Automation, Kunming University of Science and Technology, Kunming 650051, China
}

A high-precision real-time guide method for solar telescope is introduced in this paper. Since the Solar Magnetism and Activity Telescope (SMAT) has operated for nearly 10 years at Huairou Solar Observing Station, National Astronomical Observatories, some devices have become aging and the system performance has greatly decreased. For performing the technical renovation and transformation, studying a new high-precision auto-guide system for solar telescope was an important and essential job instead of the old guide system. The auto-guiding system goes through a point-line-plane model development in solar telescopes. The new system was based on full-disk solar images which were collected from the main telescope in real-time. The technology of large area CCD array has already substituted the point or line array model in the auto-guide system. We locate the center of the full-disk solar images which recorded by large array CCD image sensor in real time and eliminate noise caused by bad weather, such as clouds and fog, as well as improving computational accuracy of centroid, by setting gray threshold, determining the location of centroid, and using the ratio of the length major axis to the length of minor axis to quantify the deviation from a perfect disk. The deviation is analyzed and changed into control signal, which, through connection-oriented TCP/IP network, drives the motor to adjust the axis of telescope. The system is close-loop control. The above-mentioned method, combining hardware architecture with software algorithms, improves the precision of guide along with stability. Moreover, the connection-oriented TCP/IP network improves the efficiency, reliability and compatibility of the system. An Ethernet interface is also provided for remote control. From the testing results, there was a periodic oscillation which badly influences the tracking accuracy of solar telescope in perpetual motion in RA direction. However, there was a stationary phase on which the deviation is within 3 pixels between two periodic oscillations last for $30 \mathrm{~s}$. We could make a prediction to remind the observers when the telescope arrives the stationary phases during the solar magnetic field observing. In the observation, the precision of this new method is about 5 pixels up and down in the RA direction besides a few of points. In the DEC direction, the precision attained to 2.5 pixels. In addition, the position of the solar in the image was still stay where it was after one hour in the observation. The results show that the new method could make the solar telescope steadily accurately track the solar.

solar telescope, high-precision guide, TCP/IP communication, large array CCD guide

doi: 10.1360/N972015-00870 